\title{
EVIDENCE OF SELF-RECRUITMENT IN DEMERSAL MARINE POPULATIONS
}

\author{
Stephen E. Swearer, Jeffrey S. Shima, Michael E. Hellberg, \\ Simon R. Thorrold, Geoffrey P. Jones, D. Ross Robertson, \\ Steven G. Morgan, Kimberly A. Selkoe, Gregory M. Ruiz \\ and Robert R. Warner
}

\begin{abstract}
The majority of shallow-water marine species have a two-phase life cycle in which relatively sedentary, demersal adults produce pelagic larvae. Because these larval stages are potentially subject to dispersal by ocean currents, it has been widely accepted that local populations are open, with recruitment resulting from the arrival of larvae from non-local sources. However, a growing number of studies indicate that larvae are capable of recruiting back to their source population. Here, we review the evidence for selfrecruitment in demersal marine populations, drawing from studies of endemism, introduced species, population genetics, stock-recruitment relationships, larval distributions, populations at the limit of a species' range, and applications of environmental and chemical markers. These studies indicate that self-recruitment can and does occur across species representative of most life history traits and geographical localities. Thus, the ability of larvae to recruit back to their natal population may be a pervasive phenomenon among marine species. The mounting evidence in support of self-recruitment dynamics indicates a pressing need for a reevaluation of the appropriateness of demographically-open population models and their applicability to the management and conservation of marine ecosystems.
\end{abstract}

Until the early 20th century, marine systems were considered analogous to many terrestrial systems that consist of groups of demographically-closed or self-recruiting populations in which reproduction by local adults gives rise to the next generation. For many pelagic fisheries, it was believed that fluctuations in abundance were caused by adult migration, with poor fishing years a result of few fish returning to the usual fishing grounds. Hjort (1914) marked the beginning of a paradigm shift away from the migration theory to the view that fluctuations in adult abundance might be caused by variable recruitment (Sinclair, 1997). This shift in focus towards the early life history stages highlighted important differences in the life cycles of terrestrial and marine fauna.

The majority of shallow-water marine taxa have a bipartite life cycle in which relatively sedentary, demersal adult stages produce larvae that develop in the pelagic environment before recruiting to the benthos. Because many pelagic larval stages are too small to contend with ocean currents, Thorson (1950) proposed that recruitment variability was primarily determined by larval mortality resulting from advection away from suitable settlement sites. If pelagic larvae are subject to transport by ocean currents away from the parental population, local marine populations should be demographically open with local recruitment resulting from the transport of larvae from non-local sources. Since the 1950's, the demographically open population model has gained wide acceptance (e.g., Roughgarden et al., 1985; Sale, 1991; see Caley et al., 1996 for a review). 
A variety of observations have been commonly cited in support of an open population model:

(1) Most demersal marine species have evolved pelagic eggs and/or pelagic larvae capable of dispersal over large distances (see Grosberg and Levitan, 1992).

(2) Pelagic eggs and young larvae are small and poorly developed, analogous to passive particles, and therefore subject to transport by currents (e.g., Williams et al., 1984).

(3) Larvae have been found hundreds of kilometers away from suitable adult habitat (e.g., Sale, 1970; Scheltema, 1986; Victor, 1987; Leis, 1991)

(4) Significant gene flow exists among isolated populations distributed over wide geographic regions (e.g., Winans, 1980; Nishida and Lucas, 1988; Doherty et al., 1995; Shulman and Bermingham, 1995).

(5) Local recruitment is often highly unpredictable and uncorrelated to local production (see Sale, 1991; Caley et al., 1996).

However, there are alternative interpretations to these findings that do not require an open population model. First, the pervasiveness of pelagic larval development is not necessarily a result of selection for non-local dispersal. For example, larval development in the plankton could be a strategy to either: (1) minimize predation risk from demersal predators, (2) increase accessibility to richer food resources, or (3) break parasite cycles (see Strathmann et al., this issue). For these hypotheses, dispersal away from suitable adult habitat is an occasional and unavoidable consequence of pelagic larval development. Second, there is mounting evidence that larvae are not simply passive particles, but in fact, exhibit a variety of behaviors which, alone or in response to local oceanographic conditions, can strongly influence their dispersal (see Kingsford et al., this issue; Sponaugle et al., this issue). Third, while the capacity for long-distance dispersal exists in a variety of taxa, it is not known if larvae found far from suitable adult habitat typically survive to recruit (e.g., Cowen et al., 2000) or whether long-distance dispersal represents the predominant dispersal pattern among successful recruits. Fourth, just a few migrants per generation can maintain genetic homogeneity of neutral genetic markers among populations (Wright, 1951; Slatkin, 1985). This number is demographically trivial because recruitment events to local populations typically consist of orders of magnitude more individuals. Also, in contrast to previous findings, a growing number of studies using more sensitive molecular techniques have found gene frequency differences between neighboring populations of marine species, including those with pelagic larval stages capable of significant dispersal (see Hellberg et al., this issue). Lastly, decoupling between local production and recruitment can result from variability in larval survival, independent of the sources of larvae (e.g., the poor predictive power of many stock-recruitment relationships).

Determining the degree to which marine populations are sustained by self-recruitment or dispersal of larvae from external sources is one of the greatest challenges facing marine ecologists today. Evaluating the origins of recruiting larvae has been limited by the logistical difficulties in tracking individuals throughout a larval period that can range up to several months. Because of the small size of most larval stages and the dynamic nature of the pelagic environment, only a few taxa with very short larval periods (e.g., ascidians: Olson, 1986; Young, 1986; corals: Willis, 1990) have been followed from release to settlement. While larval tracking is the most direct method for identifying self-recruitment, it is usually logistically infeasible. In the following sections, we discuss a variety of more 
widely applicable approaches for evaluating the prevalence of self-recruitment, review the evidence for local larval retention, and highlight the diversity of life history characteristics associated with self-recruitment in marine populations. The purpose of this review is not to suggest that larval dispersal among populations does not occur, but to provide evidence that, in many instances, recruitment may often result from the retention of locally produced larvae.

\section{THe EvidenCE}

Endemic Species.-Endemic species, by definition, represent closed systems. Of particular interest are species endemic to small regions, such as isolated islands and seamounts, where recruitment over very long periods of time must have resulted solely from local reproduction. Such local endemic species provide a unique opportunity to evaluate not only what types of taxa are capable of self-recruiting but also the biological and life history traits associated with self-recruitment.

On isolated islands and archipelagos, rates of endemism within many marine taxa are often substantial. For example, within the shorefish fauna of the Central Atlantic and Eastern Pacific islands, levels of endemism range from 3-25\% (Robertson, 2001). Similarly, within the molluscan fauna on isolated tropical Pacific islands and archipelagos, levels of endemism range from 18-42\% (Kay, 1979; 1991; Rehder, 1980; Brook, 1998). If populations that colonize remote habitats are under stronger selection for local retention than less isolated localities, then we would expect small island endemics to exhibit specialized life history traits that facilitate self-recruitment. Alternatively, if self-recruitment is a general feature of most populations and the greater degree of isolation among island endemics has simply led to speciation without any further selection for self-recruitment, we would expect no consistent life history differences among endemics and more widespread species.

What life history characteristics might be associated with endemism? Conditions facilitating self-recruitment may be temporally and spatially rare such that only populations with large reproductive potential are capable of producing some self-recruiting larvae. In other words, self-recruitment may only occur by chance. Alternatively, self-recruiting species may exhibit reproductive traits that increase the per capita probability of local larval retention. Some measurable life history traits that could influence reproductive capacity and/or the probability of local larval retention are outlined in Table 1. Characteristics that are likely to increase the numbers of self-recruiting larvae in the absence of specific adaptations facilitating local larval retention include: adult traits that increase reproductive capacity (increased longevity, large size, rapid growth, early maturation), adult behaviors that increase fertilization rates and propagule survival (spawning synchrony and aggregation), and reproductive traits that increase the number of young in a brood (indirect development with small eggs). Characteristics that are likely to increase the probability of self-recruitment by individual larvae include: increased spawning at times and locations most favorable for larval retention, developmental modes that reduce the risk of passive dispersal (absent or shortened pelagic stage, demersal rather than pelagic eggs, rapid development of pelagic eggs), and propagule traits that increase active control over dispersal (large hatchlings and recruits, increased swimming and/or sensory capabilities). 
Robertson (2001) compared the biological characteristics of 88 endemic shorefishes from seven of the smallest, most isolated islands in the tropical eastern Pacific and central Atlantic. He found that the combined island-endemic fauna is representative of the regional faunas in terms of relative species richness per family. As with the vast majority of reef fishes, all endemics belonged to taxa that produce pelagic larvae. Furthermore, there were no differences between the endemic and regional faunas in terms of the proportions of species that produce pelagic versus demersal eggs. Among the endemic taxa, larval size and form varied greatly and there was no evidence that the endemic species had relatively short larval durations. If anything, the larval durations of the small-island endemics of the tropical eastern Pacific were longer than the larval durations of the regional congenerics (Victor and Wellington, 2000), a trend also observed in some Hawaiian endemic fishes (Cowen and Sponaugle, 1997). For adults, the endemics differed greatly in size, but were near average-sized members of their genera. Since longevity generally increases with body size among fishes, the longevity of endemics likely varied greatly among genera but was near average within genera. Thus, within the endemic shorefishes of the central Atlantic and eastern Pacific, none of the predicted life history traits were clearly associated with self-recruitment (Table 1).

In a survey of faunal lists of the shallow water marine molluscs of Easter Island, and the Hawaiian, Kermadec, and Galapagos archipelagos, Selkoe (unpubl. data) classified a total of 460 endemic species from 113 families based on whether their larvae are likely to be pelagic or non-pelagic (direct developers, demersal, or pelagic larvae with larval durations $<3 \mathrm{~d}$ ). Since direct information on larval development was lacking for most endemic species, she assigned development mode for each endemic species from data on confamilial non-endemic species, limiting the analysis to families exhibiting only a single development mode. If endemism in marine molluscs requires traits favoring larval retention, the majority of endemics should be representative of families with greater propensity for non-pelagic development. However, from this analysis, $31 \%$ of the endemic species were from families characterized exclusively by species with pelagic development. In contrast, $15 \%$ came from families whose species characteristically lack pelagic development. This result indicates that self-recruitment occurs quite commonly in molluscs with pelagic larvae and suggests that pelagic larval development may facilitate colonization of remote habitats (e.g., Scheltema and Williams, 1983; Leal and Bouchet, 1991; but see Johannesson, 1988 for a counter example). Overall, the presumed dispersal characteristics of endemic species and the total local molluscan fauna were indistinguishable (31\% of endemics and $32 \%$ of the total local fauna were from families with only pelagic larval development).

Levels of endemism on seamounts can also be substantial (e.g., 29-34\%) and there can be very little overlap in community composition between seamounts separated by less than $1000 \mathrm{~km}$ (Richer de Forges et al., 2000), suggesting limited dispersal between populations. Parker and Tunnicliffe (1994), in a survey of demersal invertebrates on Cobb seamount, found greater percentages of non-endemic species with either short-lived or no pelagic larval stages relative to the regional fauna. They hypothesized that these life histories were more favorable for larval retention in seamount-generated flows (e.g., Mullineaux and Mills, 1997) with adult rafting on kelp mats the likely mode of initial colonization. What remains to be investigated is whether seamount endemics also show a bias towards direct development or short-lived larval stages compared to the regional continental shelf fauna. 
Table 1. Predicted biases in life history traits of endemic species relative to resident non-endemic species.

\begin{tabular}{|c|c|c|c|c|}
\hline \multirow[t]{2}{*}{ Character } & \multicolumn{2}{|c|}{ Increased production of self-recruits } & \multicolumn{2}{|c|}{ Increased success of self-recruits } \\
\hline & Prediction & Evidence? & Prediction & Evidence? \\
\hline Developmental mode & $\begin{array}{l}\text { Indirect- } \\
\text { more young/brood }\end{array}$ & $\begin{array}{l}\text { Fishes- no } \\
\text { Molluscs- no }\end{array}$ & $\begin{array}{l}\text { Direct- reduced transport } \\
\text { away from source }\end{array}$ & $\begin{array}{l}\text { Fishes- no } \\
\text { Molluscs- no }\end{array}$ \\
\hline \multicolumn{5}{|l|}{ Larval biology } \\
\hline Initial propagule type & $\begin{array}{l}\text { Pelagic egg- } \\
\text { more young/brood }\end{array}$ & Fishes- no & $\begin{array}{l}\text { Larva- greater control over } \\
\text { dispersal }\end{array}$ & Fishes- no \\
\hline Egg size & $\begin{array}{l}\text { Smaller- } \\
\text { more young/brood }\end{array}$ & No data & $\begin{array}{l}\text { Demersal: larger- greater } \\
\text { control over dispersal } \\
\text { Pelagic: smaller- faster } \\
\text { hatching for greater control } \\
\text { over dispersal }\end{array}$ & No data \\
\hline Hatchling size & No prediction & - & $\begin{array}{l}\text { Larger-greater control over } \\
\text { dispersal }\end{array}$ & No data \\
\hline Recruit size & No prediction & - & $\begin{array}{l}\text { Larger- greater homing } \\
\text { capacity }\end{array}$ & No data \\
\hline Larval duration & No prediction & - & $\begin{array}{l}\text { Shorter- reduced transport } \\
\text { away from source }\end{array}$ & Fishes- no \\
\hline Swimming capability & No prediction & - & $\begin{array}{l}\text { Higher- greater homing } \\
\text { capacity }\end{array}$ & No data \\
\hline Sensory capability & No prediction & - & $\begin{array}{l}\text { More developed- greater } \\
\text { homing capacity }\end{array}$ & No data \\
\hline \multicolumn{5}{|l|}{ Adult biology } \\
\hline Longevity & $\begin{array}{l}\text { Higher- buffers } \\
\text { recruitment failure }\end{array}$ & Fishes- no? & No prediction & - \\
\hline Growth & $\begin{array}{l}\text { Faster- earlier maturity, } \\
\text { greater per cap. } \\
\text { fecundity }\end{array}$ & No data & No prediction & \\
\hline Size & $\begin{array}{l}\text { Larger- greater per cap. } \\
\text { fecundity }\end{array}$ & Fishes- no & No prediction & - \\
\hline Abundance & $\begin{array}{l}\text { Higher- greater pop. } \\
\text { fecundity }\end{array}$ & Fishes- no? & No prediction & - \\
\hline Synchronous spawning & $\begin{array}{l}\text { Higher- increased fert./ } \\
\text { propagule survival }\end{array}$ & No data & $\begin{array}{l}\text { Higher- reproducing at } \\
\text { times favorable for } \\
\text { retention }\end{array}$ & No data \\
\hline Aggregative spawning & $\begin{array}{l}\text { Higher- increased fert./ } \\
\text { propagule survival }\end{array}$ & No data & $\begin{array}{l}\text { Higher- reproducing at } \\
\text { locations favorable for } \\
\text { retention }\end{array}$ & No data \\
\hline
\end{tabular}

Overall, the evidence suggests that there has not been strong selection for retentionfavorable life history characteristics among these isolated endemic species. However, this does not preclude the possibility that retention-favorable life history traits may not enhance self-recruitment in other populations. In isolated habitats, colonization likely favors species capable of long-distance larval dispersal. Local populations may then become established because of circulation patterns (see Sponaugle et al., this issue) and/or larval behaviors (see Kingsford et al., this issue) that facilitate retention. Thus, while the lack of retention-favorable traits among isolated endemics may reflect the legacy of selection for colonization, it is clear that self-recruitment can and does occur even in the absence of such traits.

INTRODUCED SPECIES. - The initial establishment of non-native taxa, whether intentionally or unintentionally, can only result if the invasive population is self-recruiting; it is the only source of local recruits. Like endemic species, successful introductions provide an opportunity to evaluate the life history characteristics and geographical settings associated with self-recruitment. In particular, within-species comparisons of successfully and unsuccessfully established populations could be used to determine the environmental 
conditions favorable for self-recruitment. Unfortunately, information on the release of the same species across numerous locations is limited because (1) intentional release is rare in marine systems and (2) the actual means of introduction is often unknown and may greatly influence the success of the introduction.

Among-species comparisons of successfully and unsuccessfully established populations at the same locality could indicate the life history traits that facilitate self-recruitment. However, detailed knowledge of larval supply (i.e., the number of larvae per transfer and the frequency of transfer) for all species is uncommon. In situations where data are available, the optimal approach would be to evaluate locations with only a single applicant pool, or source of potential introductions, and identify those taxa that were successful. This requires that all species have equal opportunity for establishment. In other words, each species in the pool must have access to the transfer mechanism or vector, as well as sufficient post-settlement resources.

An informative comparison can be made of the shorefish introductions to the Hawaiian islands. Since the early 1900s, at least 33 species of marine and salt-water tolerant fish have been introduced, both intentionally and unintentionally, with at least 16 species (48\%) establishing self-recruiting populations (Table 2). This percentage is most likely an underestimate of the likelihood of establishment because some introductions failed either due to environmental requirements not found in the islands (e.g., salmonids) or because fish were introduced in numbers potentially too small to establish a resident breeding population. Although we cannot refute the possibility of unrecorded and unsuccessful introductions, which would result in an overestimate of the probability of establishment, many such attempts were likely unlicensed introductions and may have failed as a result of small numbers of fish released (i.e., inviable population sizes). Among the established species, there are no common life history traits. Although many of the species have life history characteristics that likely facilitate self-recruitment (e.g., viviparity, demersal eggs), there are genera (e.g., Lutjanidae) with pelagic eggs and moderately long larval development periods that have also become established. Interestingly, the groupers and rock cods (Serranidae), which have similar reproductive characteristics to lutjanids, were only marginally successful ( 1 out of 7 ) at establishing breeding populations. Many groupers are solitary but migrate, repeatedly and consistently, to traditional spawning localities (Thresher, 1984). The failure of most species of groupers to establish breeding populations in Hawaii could have resulted from the lack of established spawning locations that facilitate aggregation of reproductively active individuals. Thus, within the shorefish introductions to the Hawaiian islands, (1) established species do not show consistent life history traits distinct from non-established species and (2) the failure of certain species to become established likely resulted from constraints other than the ability of larvae to self-recruit.

Another informative characteristic of successful introductions is the rate of spread, which can be used as a measure of demographically important larval dispersal and therefore, the scale at which populations may be self-recruiting. For example, Crisp (1958) documented the rate of spread of the Indo-Pacific barnacle, Elminius modestus, throughout Great Britain and Europe. From an introduction occurring sometime during World War II, Crisp estimated that Elminius spread at a rate of $20-30 \mathrm{~km} \mathrm{yr}^{-1}$. Although the rate of secondary spread indicated that some larvae were dispersing moderate distances, the rapid decline in density with increasing distance from the main population suggested that the majority of larvae were self-recruiting at relatively small spatial scales $(<30 \mathrm{~km})$, a 


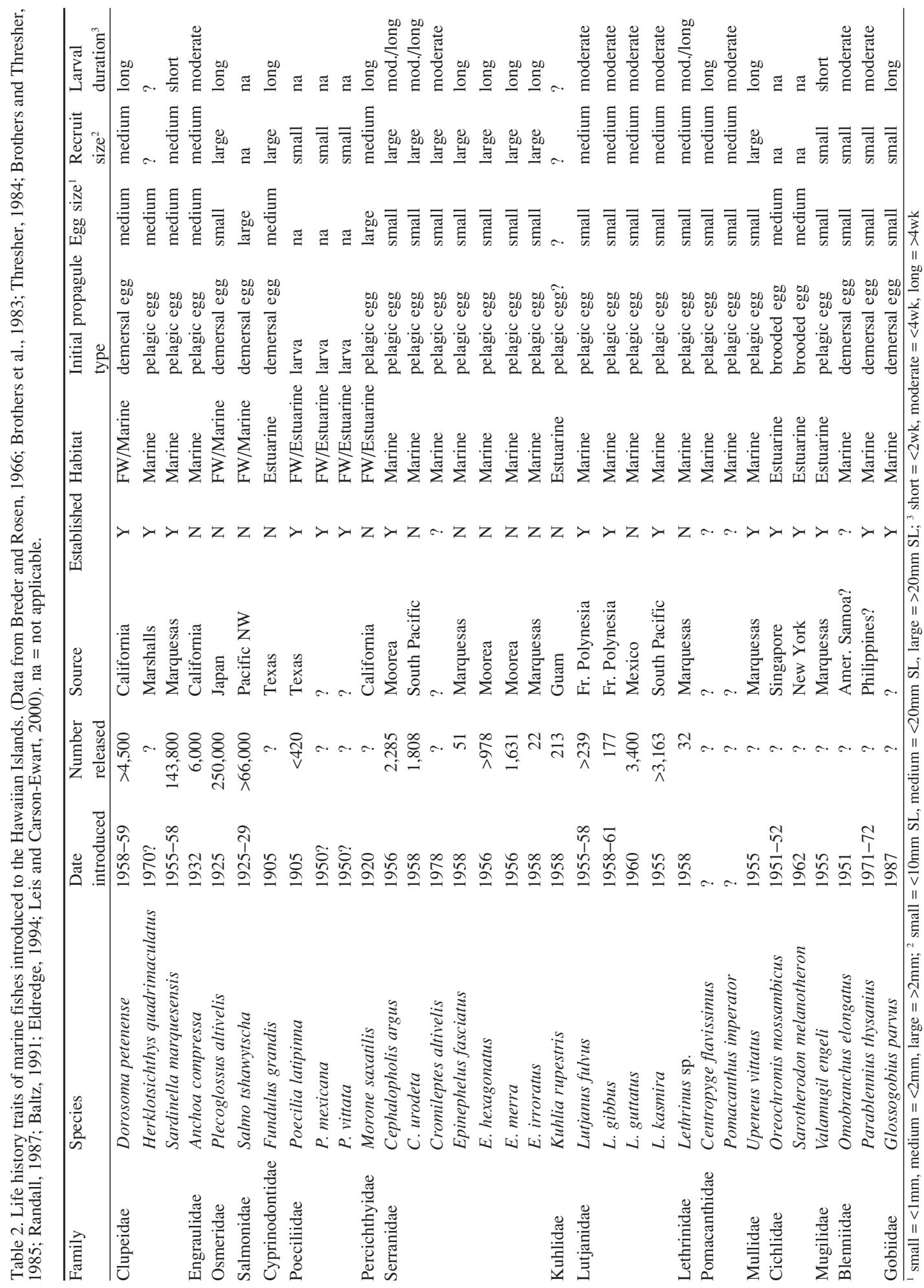


scale much smaller than would be predicted given the species' moderately long pelagic larval development period (17-34 d: Geller, 1994). Similarly, the European green crab, Carcinus maenas, introduced into San Francisco Bay in 1989/1990 has spread at a similar rate (Grosholz, 1996). Grosholz and Ruiz (1995) documented the appearance of $C$. maenas in several bays and estuaries within $70 \mathrm{~km}$ north of San Francisco Bay that resulted from the settlement of a single larval cohort. They concluded that these populations persist primarily through self-recruitment with episodic northward dispersal resulting in the establishment of new populations. Most striking is the rate of spread of the intertidal mussel, Mytilus galloprovincialis, in South Africa. McQuaid and Phillips (2000) estimated that the maximum effective dispersal of larvae was on the order of $100 \mathrm{~km}$. However, over 4 yrs after the introduction, $90 \%$ of the recruitment occurred within $5 \mathrm{~km}$ of the parent population. Thus, the distribution and age structure of recruits of these introduced species are indicative of extensive self-recruitment.

Population Genetics.-As little as one migrant moving between populations each generation can hinder the genetic divergence of populations (Wright, 1951). Furthermore, populations that are no longer demographically linked may remain genetically homogeneous until sufficient time passes to evolve genetic differences (generally hundreds to thousands of generations). Given this sensitivity to migration and the possibility of long time lags, genetic heterogeneity at a neutral genetic marker should indicate significant reproduction isolation. Thus, population genetic studies can provide compelling evidence for long-term local retention (see Hellberg et al., this issue).

Predictably, species whose larvae lack pelagic development (e.g., a reef fish: Doherty et al., 1994; prosobranch gastropods: Hoskin, 1997) often show gene frequency differences among populations. Population subdivision is also apparent in situations where larval dispersal is physically constrained by physical barriers (e.g., estuarine fish: Johnson et al., 1994; oysters: Hare and Avise, 1996). However, genetic studies have also revealed some surprises. For example, copepods inhabiting high intertidal splashpools separated by as little as $10 \mathrm{~km}$ exhibit strong population subdivision, despite having larvae capable of pelagic dispersal (Burton and Feldman, 1981; Burton, 1998). The larvae of abalone are capable of moderate dispersal over their 7-10 d pelagic development period, yet Jiang et al. (1995) found fixed mtDNA differences between populations of Haliotis diversicolor separated by just 10s of km. Reef associated fishes (Planes et al., 1996, 1998) and stomatopods (Barber et al., 2000) with even longer larval periods (weeks to months) can show genetic differentiation at similarly small spatial scales. In these instances, larval behavior and the timing of reproduction may limit the degree of dispersal relative to expectations based on assumptions of passive transport.

Some marine populations exhibit patterns consistent with genetic exchange occurring primarily between neighboring populations; nearby populations are more genetically similar than distant ones (Kimura and Weiss, 1964). Species with limited larval dispersal capabilities often exhibit such patterns (e.g., solitary coral: Hellberg, 1995). However, some species with greater larval dispersal potential also show patterns of isolation by distance (e.g., abalone: Brown, 1991; urchins: Palumbi et al., 1997; cod: Pogson et al., 2001). A correlation between genetic differentiation and distance may appear only at intermediate spatial scales, with no differentiation at smaller scales and genetic disequilibria dictated by historical demography ruling at larger scales (solitary corals: Hellberg, 1995; crabs: Lavery et al., 1995; surgeonfish: Planes et al., 1996; see Hellberg et al., this issue). 
Temporal sampling can strengthen the inference that populations showing strong genetic differences are closed. In the simplest case, such sampling can demonstrate that strong differences remain constant over time (Lessios et al., 1994; Burton, 1997). In the presence of genetic differences among local populations, similar gene frequencies across multiple age classes within a population indicate persistent self-recruitment (e.g., scallops: Lewis and Thorpe, 1994). The extent of larval retention can also depend on local population density. Benzie and Stoddart (1992) found genetic divergence increased with geographic distance for low density populations of the crown-of-thorns seastar, but not for rapidly increasing populations, suggesting that self-recruitment was greater (or genetic drift was stronger) in low density populations.

Over the long term, larval retention may reproductively isolate populations and facilitate the formation of new species. Although geographical ranges may shift over time, most closely related pairs of marine species often have abutting, or even overlapping, geographical ranges (shrimp: Duffy, 1996; gastropods: Hellberg, 1998; rockfish: Johns and Avise, 1998; barnacles: Wares et al., 2001). The isolation leading to speciation may thus have occurred at small spatial scales (100s rather than $1000 \mathrm{~s}$ of $\mathrm{km}$ ), implying that larval retention for each of the incipient species must have occurred at an even smaller scale. Paleontological studies further support this notion. For example, Cheetham and Jackson (1996) traced geographic patterns of cladogenesis using the detailed fossil record of Caribbean bryozoans and found that species of the genus Metrarabdotos formed within restricted geographical regions (on the order of $100 \mathrm{~s}$ of $\mathrm{km}$ ). To date, this pattern of sympatric sister species appears only in coastal species. Future work on insular taxa should reveal whether this is a general pattern in the ocean or one particular to continental margins.

Stock-Recruitment Relationships.- Stock-recruitment relationships observed over small spatial scales (e.g., 10s of $\mathrm{km}$ ) are consistent with self-recruitment and have been documented for species exhibiting a wide range of pelagic larval development periods: corals (1-7 d: Johnson, 1992; Hughes et al., 2000), abalone (7-10 d: Shepherd and Partington, 1995), alpheid shrimp (1-2 wks: Knowlton and Keller, 1986), scallops (1-2 wks: Arnold et al., 1998), mussels (4-5 wks: Harris et al., 1998), and reef fishes (2.5-5 wks; Robertson et al., 1988; Doherty, 1991; Meekan et al., 1993). However, temporal concordance between production and recruitment is not conclusive evidence of self-recruitment as it may arise from a variety of alternative mechanisms such as: (1) positive temporal covariation between local and global reproductive output (cf Hunt von Herbing and Hunte, 1991; Robertson et al., 1999), (2) settlement cues provided by local conspecific adults (e.g., Sweatman, 1985), and (3) positive spatial covariation between local reproductive output and suitable resources for recruits (Dye et al., 1997). Also, a lack of concordance does not negate self-recruitment since pelagic processes can interject considerable variability into the timing and magnitude of recruitment.

Stronger evidence for self-recruitment based upon stock-recruitment relationships may be derived from studies that quantify local recruitment following localized stock enhancements subsequent to large-scale mass mortality events. Such manipulations uncouple local from global reproductive output and can be used to evaluate the role of self-recruitment in the replenishment of local populations. Restocking by addition of adults has been attempted for collapsed populations of bay scallops (Argopecten irradians, pelagic larval duration of 1-2 wks, Sastry, 1965) on the Atlantic coast of the U.S. Two studies of the effects of this program indicated substantial larval retention as evidenced by elevated 
local recruitment at the restocked sites (Tettelbach and Wenczel, 1993; Peterson et al., 1996).

Another useful approach may be to evaluate stock-recruitment relationships over a range of spatial and temporal scales. McGarvey et al. (1993) used time series data to generate stock-recruitment relationships for sea scallops within and among sub-regions of the Georges Bank. Based upon stronger stock-recruitment correlations within subregions and/or among neighboring sub-regions, the authors concluded that self-recruitment occurs primarily at the sub-region scale for this species. Similarly, Hughes et al. (2000) used a hierarchical sampling design to explore relationships between the reproductive output and subsequent recruitment of acroporid corals over spatial scales ranging from meters to 100 s of kilometers. Their results indicate the strongest correlations between fecundity and recruitment within individual reefs (a few $\mathrm{km}$ ) and among reefs separated by $10 \mathrm{~s}$ of $\mathrm{km}$, suggesting acroporid corals are likely self-recruiting at these scales.

Again, such correlations are not definitive evidence for self-recruitment as they may result from numerous alternative mechanisms. In some cases, alternative hypotheses may be refuted with the implementation of creative sampling methods or focused field experiments. For example, Knowlton and Keller (1986) surgically manipulated fertility of adult pairs of alpheid shrimp to uncouple local reproductive output from settlement cues potentially arising from the presence of conspecific adults. Interestingly, they observed enhanced recruitment of alpheid shrimp within $6 \mathrm{~m}$ of fertile adults (relative to pairs that were rendered infertile), suggesting recruits may settle extraordinarily close to parents.

LARVAL Distributions.- - That pelagic larvae of shallow-water fauna are not lost at sea was recognized long ago because the vast majority of larvae occur over continental shelves, where they were spawned, rather than in the ocean basin (Mileikovsky, 1968; Makarov, 1969). Thus, the extent to which larvae tend to remain near their source population may be related to the magnitude of self-recruitment. The concept is simple; the closer that larvae remain to the source population, the greater the probability of recruiting back to the same population.

Some of the most compelling indirect evidence supporting this hypothesis comes from isolated habitats such as islands and estuaries. If habitat associations are obligate for demersal adult stages, larvae originating from these environments must return at the end of the larval period in order to survive. Because islands and estuaries are often patchily distributed, larval dispersal of many taxa may be limited to ensure successful settlement into appropriate demersal habitats at the end of the pelagic development period. Around islands, distinct larval assemblages are distributed along an onshore-offshore gradient (Boehlert and Mundy, 1993). Some species may be most abundant in bays and lagoons, and at least some species of coral reef fish are capable of completing their life cycles within lagoons (Leis et al., 1998). Other species may be most abundant nearshore, often associating with topographic features that may reduce advection away from settlement habitat (e.g., Lobel and Robinson, 1986; Kobayashi, 1989; Brogan, 1994). For these larval assemblages, studies documenting the presence of all larval developmental stages within these nearshore environments provide strong evidence for self-recruitment.

More work has been conducted in estuaries than on islands, but similar conclusions have been reached. Depending on the species, larvae are: (1) released in estuaries and are retained there throughout development, (2) released in estuaries and develop in coastal waters before returning to estuaries to settle, or (3) released on the continental shelf and 
postlarvae enter estuaries before juveniles return offshore to mature and spawn (Epifanio, 1988; Laprise and Dodson, 1990; Morgan, 1995; Rothlisberg et al., 1995). For species that live in estuaries as adults, larval retention increases the likelihood of self-recruitment, whereas larval export may decrease the probability of self-recruitment. However, in contrast to expectations, larvae that develop on the shelf may recruit to adult populations as reliably as do larvae of retained species (Hovel and Morgan, 1997; Christy and Morgan, 1998). This suggests that reliable onshore/offshore transport mechanisms exist and that larval production and recruitment may be coupled, regardless of the extent of larval migration between adult and larval habitats. Thus, at the scale of the local population, the distance of the larval center of distribution from the source population may be an important indicator of self-recruitment, and evidence is mounting that many species have larval distributions closer to the source populations than previously thought.

Populations at Edges of a Species' Range.- Under unidirectional flow regimes, populations at the upcurrent edge of a species' range must be sustained by self-recruitment (e.g., Cowen and Castro, 1994). Many marine species are distributed over areas subject to predominantly unidirectional currents that frequently intersect the boundaries of their geographic ranges. Although limits to the range of a species might result from physical barriers to dispersal and colonization (Cowen, 1985; Gaylord and Gaines, 2000), habitat limitation (e.g., Brown, 1984) or physiological tolerance (Suchanek et al., 1997), populations at the upcurrent limit of the geographic range will be extremely transitory unless they have some capacity for self-recruitment.

Metapopulation theory (sensu Hanski, 1991) holds much promise for understanding population persistence in marine systems. Applications of spatially-explicit models are currently limited, however, by the lack of empirical data on rates of larval exchange among populations. Using information on the direction and strength of surface currents, Roberts (1997) characterized Caribbean islands based on the likelihood that they might act as larval suppliers and/or larval catchments. However, models that assume passive larval dispersal and net larval transport to down-current populations cannot explain the dynamics of many natural marine populations, unless there is self-recruitment in at least some sub-populations (Jones et al., 1999). Certain source locations in the Caribbean, such as Barbados, are very likely to be self-sustaining because there are no substantial upcurrent reef systems. Such populations will obviously go extinct without self-recruitment because they have no alternative supply of larvae (Cowen and Castro, 1994; Gaylord and Gaines, 2000) unless currents occasionally reverse providing opportunities for larval dispersal from typically downcurrent populations (e.g., Cowen, 1985).

Increasing information on the length of larval life, current speed and direction, and mortality rates suggest that long distance transport may be too irregular to sustain local populations of marine fishes (Cowen, 1985; Schultz and Cowen, 1994; Cowen et al., 2000). Hence, Roberts' (1997) model may over-emphasize the importance of connectivity among reefs. Similarly, hydrodynamic models are providing increasing evidence that, where currents are not strong or unidirectional, a significant proportion of larvae may not be transported far from their natal reef (Black et al., 1991; Black, 1993; Porch, 1998; Polovina et al., 1999; Cowen et al., 2000). Even without physical mechanisms, larvae may exhibit behaviors that can facilitate retention near natal populations (see Sponaugle et al., this issue; Kingsford et al., this issue). If such behavioral mechanisms can ensure self-recruitment in populations with no up-stream source, then such mechanisms can 
potentially operate in all sub-populations (see Armsworth et al., 2001 for a theoretical evaluation of the effects of larval behavior on dispersal and self-recruitment).

Unfortunately, there is too little information on temporal variability in the geographic range of marine species and the behavior of populations at the edge of the range to evaluate fully the degree to which they are open or closed. Temporally variable geographic ranges might suggest that range limits can be controlled by sporadic dispersal events (e.g., Cowen, 1985), while static ranges might argue that they are maintained by mechanisms of self-recruitment. However, exactly where we draw the limits to the range of most marine species is seldom known and our estimates of boundaries are often too broad to measure anything but dramatic changes in a species' range. In addition, detailed knowledge of small-scale oceanography may be required to assess properly the potential for larval transport to what are perceived to be upcurrent populations.

Clearly more information is needed on the behavior of peripheral populations to assess the potential importance of self-recruitment. While it is intuitively obvious that verified upcurrent source populations can only persist with some level of self-recruitment, exactly how much and at what spatial scales self-recruitment occurs requires further investigation. It could be that the estimates of approximately $30 \%$ given for reef fishes by Jones et al. (1999) and Swearer et al. (1999) are sufficient to explain the persistence of metapopulations in the regions examined.

Environmental and Chemical Markers.-Except for particular groups of organisms such as endemics and introduced species, direct evidence for self-recruitment has proved difficult to collect. It is challenging to follow even the large pelagic stages of reef fishes for more than $30 \mathrm{~min}$ (Leis et al., 1996), and the prospects of following an individual larva for the entire duration of its pelagic life appear remote. Tagging approaches would, therefore, appear to be the only direct method of quantifying the extent of self-recruitment in marine populations (see Thorrold et al., this issue). Although simple in concept, the reality is more problematic. Not only is it necessary to tag millions of eggs or earlystage larvae, but also sufficient numbers of marked individuals must be recaptured to provide a reliable estimate of the extent of self-recruitment.

A recent study by Jones et al. (1999) has shown that it is indeed possible to conduct tagrelease studies of pelagic larval stages in the marine environment. The success of this study was predicated on the development of a method for tagging large numbers of developing embryos of a damselfish, Pomacentrus amboinensis. The otoliths of millions of developing embryos, spawned on plastic tiles, were labeled by immersion in oxytetracycline at Lizard Island, in the northern Great Barrier Reef. Light traps were deployed (20$30 \mathrm{~d}$ later) to intercept late-stage pelagic larvae immediately before settlement into reef habitats. Otoliths from a total of 5000 settlement-stage fish were examined for a fluorescent mark, indicating the presence of oxytetracycline. Of these fish, 15 labeled individuals were found. Based on estimates of the proportion of the island's larval production that they tagged, Jones et al. concluded that between $15-60 \%$ of the recruits were locally produced. The study not only confirmed, for the first time, that pelagic larvae of reef fish return to their natal reef, but also that returning larvae may contribute substantially to local recruitment.

Environmental markers have proved useful natural tags of larval origin in both fish and invertebrate populations. Such markers have an advantage over conventional tags since every individual within a certain area is labeled without any handling artifacts (Thorrold et al., this issue). Calcified structures such as otoliths in larval fish may provide informa- 
tion on growth rates and ambient water chemistry, both of which may be useful as environmental markers. Swearer et al. (1999) identified, a priori, a number of characteristics of bluehead wrasse (Thalassoma bifasciatum) larvae that were considered indicative of local retention in the vicinity of the island of St. Croix. Due to coastal enrichment of primary and secondary production, they reasoned that larvae retained close to St. Croix would have higher growth rates than larvae that spent a significant amount of time in less productive oceanic waters. Similarly, nearshore enrichment of trace elements in seawater would result in elevated trace element concentrations in whole otoliths of retained larvae. Based on the prevalence of these 'retention signatures', Swearer et al. (1999) concluded that at least $50 \%$ of the larvae recruiting to St. Croix during major settlement events most likely were spawned locally.

Gaines and Bertness (1992) found that competent larvae of the barnacle Semibalanus balanoides that were spawned and developed within Narragansett Bay, Rhode Island, were $\sim 25 \%$ larger than larvae that developed in coastal waters outside the bay. Sizefrequency distributions of settlers within Narragansett Bay in each of three years were characteristic of individuals that had spent their entire larval period within the bay, indicating little influx of larvae from open coast areas. Larvae settling into open coast habitats outside the bay were more variable in size, suggesting that perhaps as many as $50 \%$ of those settlers were produced in Narragansett Bay in years when it was well flushed. This finding is supported by recent estimates of gene flow between bay and open ocean populations (Brown et al. in press) that indicate that these populations are panmictic. Thus, while levels of retention may be quite high within the bay on ecological time scales, sufficient larval exchange between populations must occur reasonably frequently to prevent genetic differentiation.

The degree to which populations are self-recruiting in marine species that undertake significant adult migrations is determined not by larval retention, but rather by the level of homing of breeding adults to natal spawning areas. Thorrold et al. (2001) assessed such natal homing in weakfish, Cynoscion regalis, using stable isotope and trace element signatures in otoliths as a natural tag of natal area. They found that spawning site fidelity to natal estuaries along the east coast of the United States ranged from $60-81 \%$ in 2 -yrold weakfish. Strikingly, a concurrent study of microsatellite and intron DNA variability in the same individual fish failed to detect any genetic differences among the relatively isolated populations throughout the $1000 \mathrm{~km}$ range of this species (Cordes, 2000). These data are easily reconciled with the results of the otolith chemistry analyses, since there is sufficient exchange, even among those estuaries with the highest levels of natal homing, to prevent genetic divergence. It does, however, serve to highlight the inability of sensitive genetic techniques to detect demographic isolation on ecological time scales.

\section{Conclusion}

Evaluating where the pelagic larval stages of demersal marine species disperse to and how these larvae manage to successfully recruit back to adult populations is not only critical for understanding the evolution of early life history stages and the dynamics of marine populations, but also in the development and implementation of management and conservation efforts. Marine ecologists have gained limited insight into the 'black box' during more than 170 yrs of investigations into larval biology (Young, 1990). But as we have reviewed here, there are a number of tools, both recent technological advancements 
and conceptual approaches, that can or have been applied to measure larval dispersal distances, the extent to which local marine populations are self-recruiting, and the life history traits and geographical settings associated with self-recruitment.

Apparently, the ability to self-recruit does not require particular life history traits and probably occurs routinely across many faunal groups. Based on the numerous examples presented, there is a diverse set of life history traits associated with species capable of self-recruiting. In comparisons between endemic and non-endemic species as well as between successfully and unsuccessfully established introduced species, there were no detectable differences in life history traits between groups. Evidence based on genetic studies, tagging studies, and local stock-recruitment relationships came from a wide range of species with varying larval development periods and initial propagule types. However, the life history information available for these comparisons is limited and future research should be directed towards evaluating the pervasiveness of self-recruitment among species with differing life histories.

Much of the evidence for self-recruitment comes from insular and estuarine populations. For species resident in such patchily distributed habitats, there may be strong selection for local larval retention since the chances of finding suitable settlement habitat greatly diminish if larvae disperse away from the parental population. In these environments, larvae may only receive sensory information about the location of where to settle from a single source. In contrast, species resident in more continuous habitats along continental shelves have greater opportunities for encountering settlement habitats beyond the local source population. Even with significant along-shore dispersal, larvae in these habitats can potentially receive continuous sensory information regarding the location of appropriate settlement habitat and therefore, may only attempt to limit offshore dispersal.

This hypothesis is generally supported by the distribution of sister species in the IndoPacific where insular species tend to have more restricted distributions compared to their sister species along continental margins (see Hellberg, 1998). However, this does not preclude significant levels of self-recruitment in populations along extensive coastlines. Along continental margins, suitable post-settlement habitat can be discontinuous. In a recent study, Rinos and Nachman (2001) found that populations of the rock-dwelling blennioid fish, Axoclinus nigricaudus, that were separated by patches of sand were more genetically distinct than populations along continuous rocky shorelines, indicating that habitat patchiness along continental shelves can lead to limited larval exchange among populations. Also, several of the examples presented here (see Introduced species, Population genetics, and Stock-Recruitment sections) indicate local larval recruitment and limited dispersal over moderate spatial scales (10s of $\mathrm{km}$ ) even in continuous habitat. Clearly, dispersal and consequent gene flow occur in many systems over large distances $(100 \mathrm{~s}$ of $\mathrm{km})$ at temporal scales that evolutionary biologists regard as frequent $(10 \mathrm{~s}-100 \mathrm{~s}$ yrs). However, considering these populations to be demographically open could have disastrous effects if management and conservation decisions ignored the likelihood that most recruitment over ecologically relevant time scales (1-20 yrs) may result from local reproduction.

To some extent, a geographical bias in the evidence for self-recruitment may be a historical artifact. More evidence for self-recruitment in insular and estuarine environments may simply reflect the attention these habitats have received in studies of larval transport and recruitment. In such habitats, larval sources and recruitment sites are limited and readily identifiable in contrast to coastlines where habitats are less restricted, with nu- 
merous potential source populations and recruitment areas (e.g., large reef matrices). In addition, our knowledge of larval dispersal and retention in other marine habitats (e.g., the deep sea, polar regions) is even more limited. Now that we have the means to detect self-recruitment under a variety of circumstances, these environments need to be revisited in order to develop a general understanding of the biological and geographical conditions associated with self-recruitment in marine populations.

The current evidence suggests that self-recruitment can occur across a wide variety of taxa and geographical settings. However, several studies that have documented self-recruitment (e.g., Jones et al., 1999; Swearer et al., 1999), also detected larval inputs from non-local sources. These studies suggest that marine populations are likely to consist of networks of variably connected populations within a metapopulation (e.g., Thorrold et al., 2001). Thus, both dispersal and retention are likely larval transport pathways in many marine systems. What remain unknown are the temporal variability and the intensity of these connections among populations and their importance relative to self-recruitment in structuring local marine populations.

\section{ACKNOWLEDGMENTS}

This work was conducted as part of the Working Group entitled Open vs. Closed Marine Populations: Synthesis and Analysis of the Evidence, supported by the National Center for Ecological Analysis and Synthesis (NCEAS), a Center funded by NSF Grant DEB-94-21535, the University of California, Santa Barbara, the California Resources Agency, and the California Environmental Protection Agency. The study was also supported by NSF Grant DEB-00-75382 to MEH and National Geographic grant 5831-96 to DRR, and by the Partnership for the Interdisciplinary Study of Coastal Oceans (PISCO), funded by the Packard Foundation. This is PISCO Contribution No. 57.

\section{Literature Cited}

Armsworth, P. R., M. K. James and L. Bode. 2001. When to press on or turn back: dispersal strategies for reef fish larvae. Amer. Nat. 157: 434-450.

Arnold, W., D. Marelli, C. Bray and M. Harrison. 1998. Recruitment of bay scallops Argopecten irradians in Floridan Gulf of Mexico waters: scales of coherence. Mar. Ecol. Prog. Ser. 170: 143-157.

Baltz, D. M. 1991. Introduced fishes in marine systems and inland seas. Biol. Conserv. 56: 151177.

Barber, P. H., S. R. Palumbi, M. V. Erdmann and M. K. Moosa. 2000. A marine Wallace's line? Nature 406: 692-693.

Benzie, J. A. H. and J. A. Stoddart. 1992. Genetic structure of outbreaking and non-outbreaking crown-of-thorns starfish (Acanthaster planci) populations on the Great Barrier Reef. Mar. Biol. 112: $119-130$.

Black, K. P. 1993. The relative importance of local retention and inter-reef dispersal of neutrally bouyant material on coral reefs. Coral Reefs 12: 43-53.

, P. J. Moran and L. S. Hammond. 1991. Numerical models show coral reefs can be selfseeding. Mar. Ecol. Prog. Ser. 74: 1-11.

Boehlert, G. W. and B. C. Mundy. 1993. Ichthyoplankton assemblages at seamounts and oceanic islands. Bull. Mar. Sci. 53: 336-361.

Breder, C. M., Jr. and D. E. Rosen. 1966. Modes of reproduction in fishes. Natural History Press, Garden City, New Jersey. 
Brogan, M. W. 1994. Distribution and retention of larval fishes near reefs in the Gulf of California. Mar. Ecol. Prog. Ser. 115: 1-13.

Brook, F. J. 1998. The coastal molluscan fauna of the northern Kermadec Islands, Southwest Pacific Ocean. J. R. Soc. N. Z. 28: 185-233.

Brothers, E. B., D. McB. Williams and P. F. Sale. 1983. Length of larval life in twelve families of fishes at "One Tree Lagoon", Great Barrier Reef, Australia. Mar. Biol. 76: 319-324.

and R. E. Thresher. 1985. Pelagic duration, dispersal, and the distribution of IndoPacific coral-reef fishes. Pages 53-69 in M. Reaka, ed. Ecology of deep and shallow reefs. NOAA Symp. Ser vol. 3. U.S. Department of Commerce, Washington, D.C.

Brown, A. F., L. M. Kann and D. M. Rand. (in press). Gene flow versus local adaptation in the acorn barnacle, Semibalanus balanoides: Insights from mtDNA polymorphisms. Evolution.

Brown, J. H. 1984. On the relationship between abundance and distribution of species. Amer. Nat. 124: 255-279.

Brown, L. D. 1991. Genetic variation and population structure in the blacktip abalone, Haliotis rubra. Aust. J. Mar Freshw. Res. 42: 77-90.

Burton, R. S. 1997. Genetic evidence for persistence of marine invertebrate populations in an ephemeral environment. Evolution 51: 993-998.

.1998. Intraspecific phylogeography across the Point Conception biogeographic boundary. Evolution 52: 734-745.

and M. W. Feldman. 1981. Population genetics of Tigriopus californicus: II. Differentiation among neighboring populations. Evolution 35: 1192-1205.

Caley, M. J., M. H. Carr, M. A. Hixon, T. P. Hughes, G. P. Jones and B. Menge. 1996. Recruitment and the local dynamics of open marine populations. Ann. Rev. Ecol. Syst. 27: 477-500.

Cheetham, A. H. and J. B. C. Jackson. 1996. Speciation, extinction, and the decline of arborescent growth in Neogene and Quaternary cheilostome Bryozoa in North America. Pages 205-233 in J. B. C. Jackson, A. F. Budd and A. G. Coates, eds. Evolution and environment in tropical America. Univ. Chicago Press, Chicago, Illinois.

Christy, J. H. and S. G. Morgan. 1998. Estuarine immigration by crab postlarvae: mechanisms, reliability and adaptive significance. Mar. Ecol. Prog. Ser. 174: 51-65.

Cordes, J. F. 2000. Application of genetic markers to provide species identification and define stock structure: analyses of selected marine species of the mid-Atlantic Bight. Thesis, College of William and Mary, Williamsburg, Virginia.

Cowen, R. K. 1985. Large scale pattern of recruitment by the labrid, Semicossyphus pulcher: Causes and implications. J. Mar. Res. 43: 719-742.

and L. R. Castro. 1994. Relation of coral reef fish larval distributions to island scale circulation around Barbados. Bull. Mar. Sci. 54: 228-244.

and S. Sponaugle. 1997. Relationships between early life history traits and recruitment among coral reef fishes. Pages 423-449 in R. C. Chambers and E. A. Trippel, editors. Early life history and recruitment in fish populations. Fish and Fisheries Series 21. Chapman and Hall, London, UK.

, K. M. M. Lwiza, S. Sponaugle, C. B. Paris and D. B. Olson. 2000. Connectivity of marine populations: open or closed? Science 287: 857-859.

Crisp, D. J. 1958. The spread of Elminius modestus Darwin in North-West Europe. J. Mar. Biol. Ass. U.K. 37: 483-520.

Doherty, P. J. 1991. Spatial and temporal patterns in recruitment. Pages 261-293 in P. F. Sale, ed. The ecology of fishes on coral reefs. Academic Press Inc, San Diego, California.

, P. Mather and S. Planes. 1994. Acanthochromis polycanthus, a fish lacking larval dispersal, has genetically differentiated populations at local and regional scales on the Great Barrier Reef. Mar. Biol. 121: 11-21. and 1995. Gene flow and larval duration in seven species of fish of the Great Barrier Reef. Ecology 76: 2373-2391. 
Duffy, J. E. 1996. Resource-associated population subdivision in a symbiotic coral-reef shrimp. Evolution 50: 360-373.

Dye, A. H., T. A. Lasiak and S. Gabula. 1997. Recovery and recruitment of the brown mussel, Perna perna (L.), in Transkei: Implications for management. S. Afr. J. Zool. 32: 118-123.

Eldredge, L. G. 1994. Perspectives in aquatic exotic species management in the Pacific islands. I. Introductions of commercially significant aquatic organisms to the Pacific islands. SPREP Reports and Studies Series no. 78. South Pacific Commission, Noumea, New Caledonia.

Epifanio, C. E. 1988. Transport of invertebrate larvae between estuaries and the continental shelf. Am. Fish. Soc. Symp. 3: 104-114.

Gaines, S. D. and M. D. Bertness. 1992. Dispersal of juveniles and variable recruitment in sessile marine species. Nature 360: 579-580.

Gaylord, B. and S. D. Gaines. 2000. Temperature or transport? Range limits in marine species mediated solely by flow. Am. Nat. 155: 769-789.

Geller, J. B. 1994. Marine biological invasions as models of dispersal: tracking secondary spread and introgressive gene flow. Calif. Coop. Ocean. Fish. Investig., Data Rpt. 35: 68-72.

Grosberg, R. K. and D. R. Levitan. 1992. For adults only? Supply-side ecology and the history of larval biology. Trends Ecol. Evol. 7: 130-133.

Grosholz, E. D. 1996. Contrasting rates of spread for introduced species in terrestrial and marine systems. Ecology 77: 1680-1686.

and G. M. Ruiz. 1995. Spread and potential impact of the recently introduced European green crab, Carcinus maenas, in central California. Mar. Biol. 122: 239-247.

Hanski, I. 1991. Single species metapopulation dynamics: concepts, models and observations. Pages 17-38 in M. E. Gilpin and I. Hanski, eds. Metapopulation dynamics. Academic Press, London, UK.

Hare, M. P. and J. C. Avise. 1996. Molecular genetic analysis of a stepped multilocus cline in the American oyster (Crassostrea virginica). Evolution 50: 2305-2315.

Harris, J., G. Branch, B. Currie, A. Dye, C. McQuaid, B. Tomalin and C. Velasquez. 1998. Spatial and temporal variability in recruitment of intertidal mussels around the coast of southern Africa. S. Afr. J. Zool. 33: 1-11.

Hellberg, M. E. 1995. Stepping-stone gene flow in the solitary coral Balanophyllia elegans: equilibrium and nonequilibrium at different spatial scales. Mar. Biol. 123: 573-581.

.1998. Sympatric sea shells along the sea's shore: the geography of speciation in the marine gastropod Tegula. Evolution 52: 1311-1324.

, R. S. Burton, J. E. Neigel, and S. R. Palumbi. 2002. Genetic assessment of connectivity among marine populations. Bull. Mar. Sci. (this issue)

Hjort, J. 1914. Fluctuations in the great fisheries of Northern Europe viewed in the light of biological research. Rapp. P.-V. Reun., Cons. Int. Explor. Mer 20: 1-13.

Hoskin, M. G. 1997. Effects of contrasting modes of larval development on the genetic structures of populations of three species of prosobranch gastropods. Mar. Biol. 127: 647-656.

Hovel, K. A. and S. G. Morgan. 1997. Planktivory as a selective force for reproductive synchrony and larval migration. Mar. Ecol. Prog. Ser. 157: 79-95.

Hughes, T. P., A. H. Baird, E. A. Dinsdale, N. A. Moltschaniwskyj, M. S. Pratchett, J. E. Tanner and B. L. Willis. 2000. Supply-side ecology works both ways: the link between benthic adults, fecundity and larval recruits. Ecology 81: 2241-2249.

Hunt von Herbing, I. and W. Hunte. 1991. Spawning and recruitment of the bluehead wrasse Thalassoma bifasciatum in Barbados, West Indies. Mar. Ecol. Prog. Ser. 72: 49-58.

Jiang L., W. L. Wu and P. C. Huang. 1995. The mitochondrial DNA of Taiwan abalone Haliotis diversicolor Reeve, 1846 (Gastropoda: Archaeogastropoda: Haliotidae). Mol. Mar. Biol. Biotechnolog. 4: 353-364.

Johannesson, K. 1988. The paradox of Rockall: why is a brooding gastropod (Littorina saxatilis) more widespread than one having a planktonic larval dispersal stage (L. littorea)? Mar. Biol. 99: 507-513. 
Johns, G. C. and J. C. Avise. 1998. Tests for ancient species flocks based on molecular phylogenetic appraisals of Sebastes rockfishes and other marine fish. Evolution 52: 1135-1146.

Johnson, K. 1992. Population dynamics of a free-living coral: recruitment, growth, and survivorship of Manicina areolata (Linneaus) on the Caribbean coast of Panama. J. Exp. Mar. Biol. Ecol. 164: 171-191.

Johnson, M. S., R. J. Watts and R. Black. 1994. High levels of genetic subdivision in peripherally isolated populations of the atherinid fish Craterocephalus capreoli in the Houtman Abrolhos Islands, Western Australia. Mar. Biol. 119: 179-184.

Jones, G. P., M. J. Milicich, M. J. Emslie and C. Lunow. 1999. Self-recruitment in a coral reef fish population. Nature 402: 802-804.

Kay, E. A. 1979. Hawaiian marine shells. Bernice P. Bishop Museum Special Publication 64. Bishop Mus. Press, Honolulu, Hawaii.

1991. The marine mollusks of the Galápagos: determinants of insular marine faunas. Pages 235-252 in M. J. James, ed. Galápagos marine invertebrates: taxonomy, biogeography, and evolution in Darwin's islands. Plenum Press, New York.

Kimura, M. and G. H. Weiss. 1964. The stepping stone model of population structure and the decrease of genetic correlation with distance. Genetics 49: 561-571.

Kingsford, M. J., J. M. Leis, A. Shanks, K. C. Lindeman, S. G. Morgan and J. Pineda. 2002. Sensory environments, larval abilities and local self-recruitment. Bull. Mar. Sci. (this issue)

Knowlton, N. and B. D. Keller. 1986. Larvae which fall far short of their potential: highly localized recruitment in an alpheid shrimp with extended larval development. Bull. Mar. Sci. 39: 213223.

Kobayashi, D. R. 1989. Fine-scale distribution of larval fishes: Patterns and processes adjacent to coral reefs in Kaneohe Bay, Hawaii [USA]. Mar. Biol. 100: 285-294.

Laprise, R. and J. J. Dodson. 1990. The mechanism of retention of pelagic tomcod, Microgadus tomcod, larvae and juveniles in the well-mixed part of the St. Lawrence Estuary. Environ. Biol. Fishes 29: 293-302.

Lavery, S., C. Moritz and D. R. Fielder. 1995. Changing patterns of population structure and gene flow at different spatial scales in Birgus latro (the coconut crab). Heredity 74: 531-541.

Leal, J. H. and P. Bouchet. 1991. Distribution patterns and dispersal of prosobranch gastropods along a seamount chain in the Atlantic Ocean. J. Mar. Biol. Ass. U.K. 71: 11-25.

Leis, J. M. 1991. The pelagic stage of reef fishes: the larval biology of coral reef fishes. Pages 183230 in P. F. Sale, editor. The ecology of fishes on coral reefs. Academic Press Inc, San Diego, California.

and B. M. Carson-Ewart. 2000. The larvae of Indo-Pacific coastal fishes: an identification guide to marine fish larvae. Brill, Leiden, The Netherlands.

, H. P. A. Sweatman and S. E. Reader. 1996. What the pelagic stages of coral reef fishes are doing in open water: daytime field observations of larval behavioural capabilities. Mar. Freshw. Res. 47: 401-411.

, T. Trnski, P. J. Doherty and V. Dufour. 1998. Replenishment of fish populations in the enclosed lagoon of Taiaro Atoll: (Tuamotu Archipelago, French Polynesia) evidence from eggs and larvae. Coral Reefs 17: 1-8.

Lessios, H. A., J. R. Weinberg and V. R. Starczak. 1994. Temporal variation in populations of the marine isopod Exocirolana: how stable are gene frequencies and morphology. Evolution 48: 549-563.

Lewis, R. I. and J. P. Thorpe. 1994. Temporal stability of gene frequencies within genetically heterogeneous populations of the queen scallop Aequipecten (Chlamys) operularis. Mar. Biol. 121: $117-126$.

Lobel, P. S. and A. R. Robinson. 1986. Transport and entrapment of fish larvae by ocean mesoscale eddies and currents in Hawaiian waters. Deep Sea Res. 33: 483-500.

Makarov, R. R. 1969. Transport and distribution of Decapoda larvae in the plankton of the Western Kamchatka Shelf. Oceanology 9: 251-261. 
McGarvey, R., F. Serchuk and I. McLaren. 1993. Spatial and parent-age analysis of stock-recruitment in the Georges Bank sea scallop (Placopecten magellanicus) population. Can. J. Fish. Aquat. Sci. 50: 564-574.

McQuaid, C. D. and T. E. Phillips. 2000. Limited wind-driven dispersal of intertidal mussel larvae: in situ evidence from the plankton and the spread of the invasive species Mytilus galloprovincialis in South Africa. Mar. Ecol. Prog. Ser. 201: 211-220.

Meekan, M. G., M. J. Milicich and P. J. Doherty. 1993. Larval production drives temporal patterns of larval supply and recruitment of a coral reef damselfish. Mar. Ecol. Prog. Ser. 93: 217-225.

Mileikovsky, S. A. 1968. Distribution of pelagic larvae of bottom invertebrates of the Norwegian and Barents Seas. Mar. Biol. 1: 161-171.

Morgan, S. G. 1995. Life and death in the plankton: larval mortality and adaptation. Pages 279-321 in L. McEdward, ed. Ecology of marine invertebrate larvae. CRC Press, Boca Raton, Florida.

Mullineaux, L. S. and S. W. Mills. 1997. A test of the larval retention hypothesis in seamountgenerated flows. Deep-Sea Res. I 44: 745-770.

Nishida, M. and J. S. Lucas. 1988. Genetic differences between geographic populations of the crown-of-thorns starfish throughout the Pacific region. Mar. Biol. 98: 359-368.

Olson, R. R. 1986. The consequences of short-distance larval dispersal in a sessile marine invertebrate. Ecology 66: 30-39.

Palumbi, S. R., G. Grabowsky, T. Duda, L. Geyer and N. Tachino. 1997. Speciation and population genetic structure in tropical Pacific sea urchins. Evolution 51: 1506-1517.

Parker, T. and V. Tunnicliffe. 1994. Dispersal strategies of the biota on an oceanic seamount: implications for ecology and biogeography. Biol. Bull. 187: 336-345.

Peterson, C., H. Summerson and R. Luettich, Jr. 1996. Response of bay scallops to spawner transplants: a test of recruitment limitation. Mar. Ecol. Prog. Ser. 132: 93-107.

Planes, S., M. Parroni and C. Chauvet. 1998. Evidence for limited gene flow in three species of coral reef fishes in the lagoon of New Caledonia. Mar. Biol. 130: 361-368.

, R. Galzin and F. Bonhomme. 1996. A genetic metapopulation model for reef fishes in oceanic islands: the case study of the surgeonfish, Acanthurus triostegus. J. Evol. Biol. 9: 103117.

Pogson, G. H., C. T. Taggart, K. A. Mesa and R. G. Boutilier. 2001. Isolation by distance in the Atlantic cod, Gadus morhua, at large and small geographic scales. Evolution 55: 131-146.

Polovina, J. J, P. Kleiber and D. R. Kobayashi. 1999. Application of TOPEX-POSEIDON satellite altimetry to simulate transport dynamics of larvae of spiny lobster, Panulirus marginatus, in the Northwestern Hawaiian Islands, 1993-1996. Fish. Bull. U.S. 97: 132-143.

Porch, C. E. 1998. A numerical study of larval fish retention along the southeast Florida coast. Ecol. Modell. 109: 35-59.

Randall, J. E. 1987. Introductions of marine fishes to the Hawaiian islands. Bull. Mar. Sci. 41: 490502.

Rehder, H. A. 1980. The marine mollusks of Easter Island (Isla de Pascua) and Sala y Gómez. Smithson. Contrib. Zool. 289: 1-167.

Richer de Forges, B., J. A. Koslow and G. C. B. Poore. 2000. Diversity and endemism of the benthic seamount fauna in the southwest Pacific. Nature 405: 944-947.

Riginos, C. and M. W. Nachman. 2001. Population subdivision in marine environments: the contributions of biogeography, geographical distance and discontinuous habitat to genetic differentiation in a blennioid fish, Axoclinus nigricaudus. Molec. Ecol. 10: 1439-1453.

Roberts, C. M. 1997. Connectivity and management of Caribbean coral reefs. Science 278: 1454 1456.

Robertson, D. R. 2001. Population maintenance among tropical reef fishes: inferences from smallisland endemics. Proc. Nat'l. Acad. Sci. 98: 5667-5670.

, D. G. Green and B. C. Victor. 1988. Temporal coupling of production and recruitment of larvae of a Caribbean reef fish. Ecology 69: 370-381. 
, S. E. Swearer, K. Kaufmann and E. B. Brothers. 1999. Settlement vs. environmental dynamics in a pelagic-spawning reef fish at Caribbean Panama. Ecol. Monogr. 69: 195218.

Rothlisberg, P. C., J. A. Church and C. B. Fandry. 1995. A mechanism for near-shore concentration and estuarine recruitment of post-larval Penaeus plebejus Hess (Decapoda, Penaeidae). Estuar. Coast. Shelf Sci. 40: 115-138.

Roughgarden, J., Y. Iwasa and C. Blaxter. 1985. Demographic theory for an open population with space-limited recruitment. Ecology 66: 54-67.

Sale, P. F. 1970. Distribution of larval Acanthuridae off Hawaii. Copeia 1970: 765-766.

1991. Reef fish communities: open nonequilibrial systems. Pages 564-598 in P. F. Sale, ed. The ecology of fishes on coral reefs. Academic Press Inc, San Diego, California.

Sastry, A. N. 1965. The development and external morphology of pelagic larval and post-larval stages of the bay scallop Aequipectin irradians concentricus Say, reared in the laboratory. Bull. Mar. Sci. 15: 417-435.

Scheltema, R. S. 1986. Long-distance dispersal by planktonic larvae of shoal-water benthic invertebrates among Central Pacific islands. Bull. Mar. Sci. 39: 241-256.

and I. P. Williams. 1983. Long-distance dispersal of planktonic larvae and the biogeography and evolution of some Polynesian and western Pacific mollusks. Bull. Mar. Sci. 33: 545-565.

Schultz, E. T. and R. K. Cowen. 1994. Recruitment of coral-reef fishes to Bermuda: local retention or long-distance transport? Mar. Ecol. Prog. Ser. 109: 15-28.

Shepherd, S. and D. Partington. 1995. Studies on southern Australian abalone (Genus Haliotis). XVI. Recruitment, habitat, and stock relations. Aust. J. Mar Freshw. Res. 46: 669-680.

Shulman, M. J. and E. Bermingham. 1995. Early life histories, ocean currents, and the population genetics of Caribbean reef fishes. Evolution 49: 897-910.

Sinclair, M. 1997. Prologue. Recruitment in fish populations: the paradigm shift generated by ICES Committee A. Pages 1-30 in R. C. Chambers and E. A. Trippel, eds. Early life history and recruitment in fish populations. Fish and Fisheries Series 21. Chapman and Hall, London, UK.

Slatkin, M. 1985. Gene flow in natural populations. Ann. Rev. Ecolog. Syst. 16: 393-430.

Sponaugle, S., R. K. Cowen, A. Shanks, S. G. Morgan, J. M. Leis, J. Pineda, G. W. Boehlert, M. J. Kingsford, K. C. Lindeman, C. Grimes and J. L. Munro. 2002. Predicting self-recruitment in marine populations: Biophysical correlates and mechanisms. Bull. Mar. Sci. (this issue)

Strathmann, R. R., T. P. Hughes. A. M. Kuris, K. Lindeman, S. G. Morgan, J. M. Pandolfi and R. R. Warner. 2002. Evolution of self-recruitment and its consequences for marine populations. Bull. Mar. Sci. (this issue)

Suchanek, T. H., J. B. Geller, B. R. Kreiser and J. B. Mitton. 1997. Zoogeographic distributions of the sibling species Mytilus galloprovincialis and M. trossulus (Bivalvia: Mytilidae) and their hybrids in the north Pacific. Biol. Bull. 193: 187-194.

Swearer, S. E., J. E. Caselle, D. W. Lea and R. R. Warner. 1999. Larval retention and recruitment in an island population of a coral-reef fish. Nature 402: 799-802.

Sweatman, H. P. A. 1985. The influence of adults of some coral reef fishes on larval recruitment. Ecol. Monogr. 55: 469-485.

Tettelbach, S. and P. Wenczel. 1993. Reseeding efforts and the status of bay scallop Argopecten irradians (Lamarck 1819) populations in New York following the occurrence of "brown tide" algal blooms. J. Shellfish Res. 12: 423-431.

Thorrold, S. R., C. Latkoczy, P. K. Swart and C. M. Jones. 2001. Natal homing in a marine fish metapopulation. Science 291: 297-299.

, G. P. Jones, M. E. Hellberg, R. S. Burton, S. E. Swearer, J. E. Neigel, S. G. Morgan and R. R. Warner. 2002. Quantifying larval retention and connectivity in marine populations with artificial and natural markers: can we do it right? Bull. Mar. Sci. (this issue)

Thorson, G. 1950. Reproductive and larval ecology of marine bottom invertebrates. Biol. Rev. Cambridge Philos. Soc. 25: 1-45. 
Thresher, R. E. 1984. Reproduction in reef fishes. T. F. H. Publications, Neptune City, New Jersey. Victor, B. C. 1987. Growth, dispersal, and identification of planktonic labrid and pomacentrid reeffish larvae in the eastern Pacific Ocean. Mar. Biol. 95: 145-152.

and G. M. Wellington. 2000. Endemism and the pelagic larval duration of reef fishes in the eastern Pacific Ocean. Mar. Ecol. Prog. Ser. 205: 241-248.

Wares, J. P. 2001. Patterns of speciation inferred from mitochondrial DNA in North American Chthamalus (Cirripedia: Balanomorpha: Chthamaloidea). Mol. Phylogenet. Evol. 18: 104-116.

Williams, D. McB., E. Wolanski and J. C. Andrews. 1984. Transport mechanisms and the potential movement of planktonic larvae in the central region of the Great Barrier Reef. Coral Reefs 3: 229-236.

Willis, B. L. and J. K. Oliver. 1990. Direct tracking of coral larvae: Implications for dispersal studies of planktonic larvae in topographically complex environments. Ophelia 32: 145-162.

Winans, G. A. 1980. Geographic variation in the milkfish Chanos chanos. I. Biochemical evidence. Evolution 34: 558-574.

Wright, S. 1951. The genetical structure of populations. Annals of Eugenics 15: 323-354.

Young, C. M. 1986. Direct observation of field swimming behavior in larvae of the colonial ascidian Ecteinascidia turbinata. Bull. Mar. Sci. 39: 279-289 32: $1-48$.

1990. Larval ecology of marine invertebrates: a sesquicentennial history. Ophelia

ADDRESSES: (S.E.S.) Department of Zoology, University of Melbourne, Victoria 3010 Australia; (J.S.S., K.A.S., R.R.W.) Department of Ecology, Evolution, and Marine Biology, University of California, Santa Barbara, California 93106. (M.E.H.) Department of Biological Sciences, 508 Life Sciences Building, Louisiana State University, Baton Rouge, Louisiana 70803. (S.R.T.) Biology Department, Woods Hole Oceanographic Institution, Woods Hole, Massachusetts 02543. (G.P.J.) School of Marine Biology and Aquaculture, James Cook University, Townsville, Queensland 4811 Australia; (D.R.R.) Smithsonian Tropical Research Institute (Panama), Unit 0948, APOAA 34002 U.S.A.; (S.G.M.) Bodega Marine Laboratory, University of California, P.O. Box 247, 2099 Westside Road, Bodega Bay, California 94923. (G.M.R.) Smithsonian Environmental Research Center, P.O. Box 28, 637 Contees Wharf Road, Edgewater, Maryland 21037. Corresponding Author: (S.E.S.) E-mail: <sswearer@unimelb.edu.au>. 